九州大学学術情報リポジトリ

Kyushu University Institutional Repository

Optimization of Stiffness Properties of Composite Sandwich using Hybrid Taguchi-GRA-PCA

Kumar, Anil

MAE Department, G B Pant Engineering College

Arindam Kumar Chanda

MAE Department, G B Pant Engineering College

Angra, Surjit

ME Department, NIT

https://doi.org/10.5109/4480708

出版情報 : Evergreen. 8 (2)，pp.310-317，2021-06. Transdisciplinary Research and Education Center for Green Technologies, Kyushu University

バージョン：

権利関係 : 


\title{
Optimization of Stiffness Properties of Composite Sandwich using Hybrid Taguchi-GRA-PCA
}

\author{
Anil Kumar ${ }^{1, *}$, Arindam Kumar Chanda ${ }^{1}$, Surjit Angra $^{2}$ \\ ${ }^{1}$ MAE Department, G B Pant Engineering College, New Delhi, 110020, India \\ ${ }^{2}$ ME Department, NIT, Kurukshetra, 136119, India \\ *Author to whom correspondence should be addressed: \\ *E-mail: anilapmae@gmail.com
}

(Received November 17, 2020; Revised April 29, 2021; accepted May 16, 2021).

\begin{abstract}
The composite sandwich structures provide the benefits of higher Strength to weight ratio, higher stiffness and flexural strength. The different properties of a sandwich structure depend on various design factors such as material of core and facesheet, thickness of facesheet and core, type of core and panel shape etc. In this study, four different factors i.e. Material of Honeycomb core, Core Height, Facesheet Thickness and Panel Width, with each having three different values have been chosen and a L9 Orthogonal has been generated using Taguchi Design in Minitab 18. After that, 9 different samples have been fabricated as per configurations of L9 OA. Then three point bending test has been performed on these samples and the values of Bending Stiffness, Rigidity and Equivalent Stiffness has been calculated .Then Taguchi Analysis has been performed on the output responses and optimum design parameters have been detected. After that PCA assisted Grey Relation Analysis has been performed on output responses and the values of optimum design parameters for sandwich structure has been obtained.
\end{abstract}

Keywords: Optimization of Stiffness Properties; Kevlar ${ }^{\circledR}$ Honeycomb Core; Hybrid Taguchi-PCA-GRA; Computational Analysis of Composite Sandwich.

\section{Introduction}

A structural composite sandwich is a unique form of a laminated composite consisting of 3 main elements i.e.

- $\quad$ Two thin and stiff faces one at top and bottom position.

- A thick, light core (of different shapes and design).

The facesheets and core are bonded with each other in such a way so that they can transfer load between the different components.

The face sheets act together to produce an efficient stress couple counteracting the external bending moment.

The core of sandwich structure opposes shear and stabilize the faces, available at the top and bottom of it, against buckling or wrinkling. It is pretty important that, the bond between the core and faces of the sandwich structure be strong enough to bear the stresses. For attaining high stiffness-to-weight and bending strength-to-weight ratio utilisation of low density core can be very effective ${ }^{11}$.

Materials and Material Properties for Sandwich Structure

a. Face sheets- Any material available in the form of thin sheet can be used to form the faces of a sandwich panel. Most widely used face materials can be of two types- metallic and non-metallic materials. Metallic facesheets are steel, stainless steel and aluminum alloys. Non Metallic materials include plywood, reinforced plastic and fibre composites.

The design of unequal ply count face sheets has higher stiffness to weight ratio when compared with the conventional symmetric sandwich structures ${ }^{2}$. The unit-cell models having shell elements equivalent to layered cell wall can be used for compression simulation ${ }^{4)}$. The thickness of facesheet has a larger impact on the flexural rigidity and sheet stress on the sandwich structure $^{5)}$. The laminates with thinner skins can lead to core crushing ${ }^{8)}$.

b. Cores- Mainly 4 types of cores are used in sandwich structures such as- Corrugated, Honeycomb, Balsa wood and Foams.

Most required property of a core of a sandwich structure is the low density to reduce the sandwich weight.

The sandwich structure is more affected by type of core material rather than the core layer thickness ${ }^{19)}$. So it can be concluded that the density, shear strength and modulus, thermal and acoustical insulation are the most important properties of a core. The stresses are highest between Land $\mathrm{W}$ directions so this direction is the panel's weakest direction. It has been observed that the weakest angle is 
$62^{\circ}$ and the L-direction is the strongest direction ${ }^{3)}$.

FEM analysis is a very strong tool for the structural analysis of the mechanism ${ }^{17)}$. The Honeycomb core can be made of metallic or non metallic materials such as -

1. Metallic Materials - Aluminum, Steel etc.

2.Non Metallic Material - Glass, Paper, and Aramid fibre mats, such as Nomex, Kevlar etc.

Due to the different manufacturing methods the different honeycombs have different in and out-of-plane properties. But, Nomex honeycomb core is weak in, out-of-plane direction. ${ }^{4)}$

c. Adhesives The purpose of an adhesive in a composite sandwich structure is to provide a good bond between the materials components. The various adhesives that are used are:

Epoxy Resins Epoxy Resins are low temperature curing material, normally between $20^{\circ} \mathrm{C}$ to $90^{\circ} \mathrm{C}$. They can be used without solvents and they have low volume shrinkage. The biggest advantage of use of epoxy is that due to the absence of solvents, epoxies can be used with almost every type of core material. The shear strength of most of the epoxies are about 20-25 MPa.

Also other adhesives are available such as-

o Phenolics

o Polyurethanes

o Urethane Acrylates

o Polyester and Vinyl ester Resins

The percentage of fiber affects the mechanical properties of the fiber-reinforced polymer composite ${ }^{21)}$. So it is has been observed that the different properties of sandwich composite structure such as Stiffness and Flexural Strength depends on various design factors such as material of core and facesheet, thickness of facesheet and core, type of core and panel shape etc.

After thorough study of past work it has been observed that-

1. Not much work has been done on sandwich structure having the commercial Kevlar Honeycomb Core Material.

2. Not much research work has been observed on optimization of stiffness properties of composite sandwich structure using Hybrid Taguchi-GRA-PCA.

So here seems an opportunity to make an analysis of stiffness properties of sandwich structure having Kevlar Honeycomb core.

The main Objective of this research is to identify the best combination of the different design factors to achieve the highest flexural stiffness, bending rigidity and panel stiffness using Hybrid Taguchi-GRA-PCA.

In this study, four different factors i.e. Material of Honeycomb core, Core Height, Facesheet Thickness and Panel Width with each having three different values will be chosen and a L9 Orthogonal will be generated using Taguchi Design in Minitab 18. After that, 9 different samples will be fabricated as per configurations of L9 OA. Then "Three point bend" test has to be performed on these samples and the values of Bending Stiffness,
Rigidity and Equivalent Stiffness has to be calculated. After that, Taguchi Analysis will be performed on the output responses and optimum design parameters will be detected. Then PCA assisted Grey Relation Analysis will be performed on output responses and again the optimum design parameters will be detected. So ultimately the objective of this research work is the multi-response optimization of stiffness properties of composite sandwich structure design parameters.

\section{Experimental Work}

\subsection{Selection Of Different Design Parameters}

Material- The following materials has been selected for face sheets, Core and Adhesive-
A. Face Sheet Material- Carbon fiber
B. Core Material- Non Metallic Materials
C. Adhesive -Epoxy

Design Parameters- The main design parameters of a composite sandwich structures are material of face sheet and core, Thickness of core, Thickness of face sheet the size of the sandwich panel to be tested. An increase in cell size leads to an increase in the shear modulus of the core which ultimately results in an increase in the stiffness of the sandwich beam and the failure of the specimen is due to the fracture of the core ${ }^{24)}$. With hexagonal composite material weight saving is $39 \%$ as compared with other composite material ${ }^{25}$.

In present research, the design parameters and their corresponding levels employed for fabrication of composite sandwich structure are-

1. Core Material- (Kevlar, Nomex and Polypropylene)

2. Core Thickness- (8mm, $10 \mathrm{~mm}$ and $12.7 \mathrm{~mm})$

3. Face sheet Thickness- $(.4 \mathrm{~mm}, .6 \mathrm{~mm}$ and $.8 \mathrm{~mm})$

4. Panel Width - (40mm, $45 \mathrm{~mm}, 50 \mathrm{~mm})$.

\subsection{TAGUCHI DESIGN}

Taguchi Design can be used as the process of optimum design of a sandwich structure and for determining the optimum geometry of the unit cell simultaneously with the material and geometric parameters of the face skins ${ }^{22}$. Different researchers and statisticians have proved that the Taguchi approach is the most helpful tool for single objective optimization.

Taguchi and GRA are best suited for finding optimum wear and friction force of the composite ${ }^{6}$. Multi-response optimization is a suitable method for optimization of different parameters ${ }^{7)},{ }^{9)},{ }^{13)}$.

Taguchi analysis has been used to prove that the uncarbonized eggshell content in AA 2014 alloy helps in improving the hardness of the composite ${ }^{18)}$.

Taguchi L9 orthogonal array has been utilized to investigate the tensile strength of Acrylo-nitrile butadiene styrene $(\mathrm{ABS})^{20)}$.

Due to its suitability, Taguchi Design has been adopted here also and for this, 4 factors with each having 3 levels 
have been utilized. These factors have been entered in MINITAB 18 software and the following L9 OA has been received as shown in table 1 below.

Table1- L9 OA obtained through Taguchi Design

\begin{tabular}{|c|c|c|c|c|}
\hline $\begin{array}{c}\text { C. } \\
\text { N. }\end{array}$ & $\begin{array}{c}\text { Core } \\
\text { Material }\end{array}$ & $\begin{array}{c}\text { Core } \\
\text { Thickness } \\
\text { (mm) }\end{array}$ & $\begin{array}{c}\text { F/sheet } \\
\text { Thickness } \\
\text { (mm) }\end{array}$ & $\begin{array}{c}\text { Panel } \\
\text { Width } \\
\text { (mm) }\end{array}$ \\
\hline 1 & PK2 & 8 & 0.4 & 40 \\
\hline 2 & PK2 & 10 & 0.6 & 45 \\
\hline 3 & PK2 & 12.7 & 0.8 & 50 \\
\hline 4 & PN2 & 8 & 0.6 & 50 \\
\hline 5 & PN2 & 10 & 0.8 & 40 \\
\hline 6 & PN2 & 12.7 & 0.4 & 45 \\
\hline 7 & PPL & 8 & 0.8 & 45 \\
\hline 8 & PPL & 10 & 0.4 & 50 \\
\hline 9 & PPL & 12.7 & 0.6 & 40 \\
\hline
\end{tabular}

\subsection{Fabrication of Sandwich Panels as Pe Taguchi Design}

The sandwich structures having the config ation as per Taguchi Design have been fabricated using the Vacuum Assisted Hand Lay-Up method. The figure 1 nicely shows the fabricated sandwich panel.

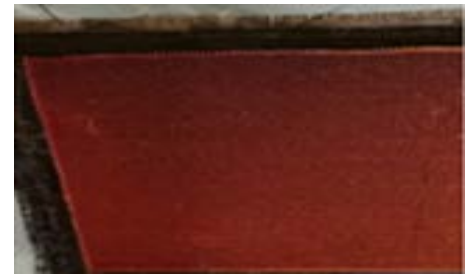

Figure 1 - Fabrication of Sandwich Panel

\subsection{Three Point Bend Test of 9 Samples as per ASTM C393}

The Three Points Bend Test has been performed for all the 9 configurations as per ASTM C393 standard $^{23)}$ and the values of ultimate load and deflection has been calculated. The figure 2 and 3 show the testing set up and specimen after testing. Figure 3 shows a test specimen after the completion of a 3 point bending test. The failure of the core is main reason behind the failure of this composite sandwich panel. The tearing apart of the two walls from each other, results in failure of the panel.

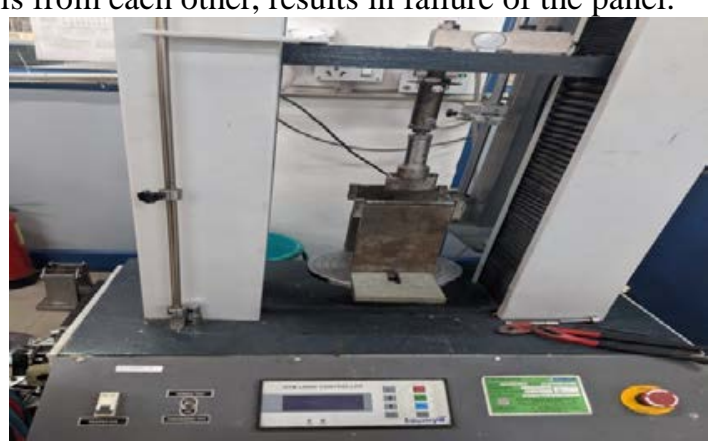

Figure 2- Three point Bend test Set

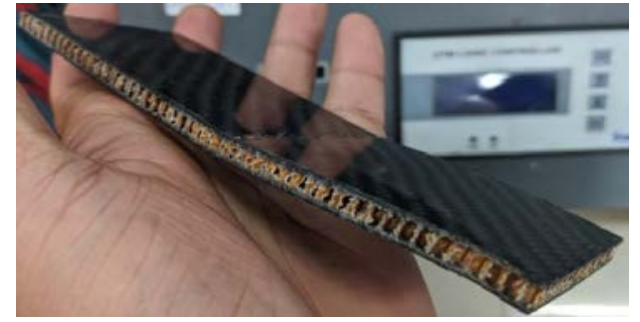

Figure 3- A Test Specimen after 3-Ponit Bend Test

\section{RESULTS}

The different sandwich properties i.e. Ultimate load, deflection and ultimately the Stiffness values, obtained for all 9 configurations have been noted and tabulated as shown below in table 2 .

"Gibson and Ashbey Model” has been used for finding the different in and Out plane properties of the commercial honeycomb core ${ }^{14)}$. The values of Bending Stiffness and Rigidity have been obtained by utilization of following formulae ${ }^{16)}$ for the two -

Bending stiffness, $\quad \mathrm{D}=\mathrm{E}\left(\mathrm{d}^{3}-\mathrm{c}^{3}\right) * \mathbf{b} / \mathbf{1 2}$

Shear panel rigidity, $\mathrm{U}=\mathbf{G}(\mathrm{d}+\mathrm{c})^{2} * \mathbf{b} / \mathbf{4 c}$

Here $\mathrm{c}=$ Core thickness $(\mathrm{mm})$

$\mathrm{t}=$ Face-sheet thickness $(\mathrm{mm})$

$\mathrm{d}=$ Thickness of Sandwich $(\mathrm{c}+2 \mathrm{t})(\mathrm{mm})$

$\mathrm{b}=$ Sandwich Width (b) (mm)

$\mathrm{L}=$ Span length (150mm)

$\mathrm{E}=$ Face Sheet Young's modulus (E) (61340 MPa)

Plascore Data sheet ${ }^{15)}$ has been used to determine the$\mathrm{G}=$ Shear modulus $(\mathrm{G})$ of core. (98-102MPa)

Table 2- Values after Analysis of Test Samples

\begin{tabular}{|c|c|c|c|c|c|}
\hline $\begin{array}{l}\text { C. } \\
\text { N. }\end{array}$ & $\begin{array}{c}\text { Load } \\
(\mathrm{N})\end{array}$ & $\begin{array}{r}\text { Defor. } \\
(\mathrm{mm})\end{array}$ & $\begin{array}{r}\text { Stiffness } \\
(\mathrm{N} / \mathrm{mm})\end{array}$ & \begin{tabular}{|c} 
Bending \\
Stiffness \\
$\left(\mathbf{M N ~ m m}^{2}\right)$
\end{tabular} & $\begin{array}{c}\text { Rigidity } \\
\text { (N) }\end{array}$ \\
\hline 1 & 1078 & 2.832 & 380.650 & 34.65137 & 37749.6 \\
\hline 2 & 1535.6 & 2.295 & 669.107 & 93.14356 & 54606.96 \\
\hline 3 & 2181 & 2.03 & 1074.384 & 223.85 & 78927.17 \\
\hline 4 & 1159.8 & 2.88 & 402.708 & 68.161 & 23112.5 \\
\hline 5 & 1168 & 2.65 & 440.755 & 114.684 & 23328 \\
\hline 6 & 1504 & 3.03 & 496.370 & 94.768 & 30403.35 \\
\hline 7 & 396.5 & 1.48 & 267.905 & 85.738 & 10890 \\
\hline 8 & 511 & 1.75 & 292.083 & 66.378 & 13520 \\
\hline 9 & 535 & 1.61 & 332.298 & 130.293 & 13928.35 \\
\hline
\end{tabular}

Failure of the Sandwich panel- After testing, the different sandwich panels have been thoroughly checked to determine the failure mode. It has been observed that the failure of the panel is due to Shear crimping which arises due to weak core in shear.

\subsection{TAGUCHI ANALYSIS}

For performing the Taguchi analysis, the three output response factors i.e. Panel Bending Stiffness (D), Bending Rigidity (U) and Equivalent Stiffness (S) have been selected and Taguchi analysis has been performed on 
individual output Parameters.

Table 3- Taguchi L9 OA with different responses

\begin{tabular}{|l|c|c|c|r|l|c|}
\hline $\begin{array}{l}\text { Core } \\
\text { Code }\end{array}$ & $\begin{array}{c}\text { CT } \\
\mathbf{m m}\end{array}$ & $\begin{array}{c}\text { FST } \\
\mathbf{m m}\end{array}$ & $\begin{array}{c}\text { PW } \\
\mathbf{m m}\end{array}$ & $\begin{array}{c}\mathbf{D} \\
\mathbf{M N m m}^{2}\end{array}$ & $\begin{array}{c}\text { U } \\
\mathbf{N}\end{array}$ & $\begin{array}{c}\text { S } \\
\mathbf{N} / \mathbf{m m}\end{array}$ \\
\hline PK2 & 8 & 4 & 40 & 34.6513 & 37749.6 & 380.650 \\
\hline PK2 & 10 & 6 & 45 & 93.1435 & 54606.9 & 669.107 \\
\hline PK2 & 12.7 & 8 & 50 & 223.85 & 78927.1 & 1074.38 \\
\hline PN2 & 8 & 6 & 50 & 68.161 & 23112.5 & 402.708 \\
\hline PN2 & 10 & 8 & 40 & 114.684 & 23328 & 440.755 \\
\hline PN2 & 12.7 & 4 & 45 & 94.768 & 30403.3 & 496.370 \\
\hline PPL & 8 & 8 & 45 & 85.738 & 10890 & 267.905 \\
\hline PPL & 10 & 4 & 50 & 66.378 & 13520 & 292.083 \\
\hline PPL & 12.7 & 6 & 40 & 130.293 & 13928.3 & 332.298 \\
\hline
\end{tabular}

Using Taguchi Analysis S/N ratio (signal to noise ratio) has been generated for all response characteristics i.e. Bending Stiffness (D) and Rigidity (U) and Stiffness and "Larger-is-better" option has been selected as the values more for the response factors will give a better sandwich structure.

Taguchi Analysis for Bending Stiffness (D), Rigidity (U) and Stiffness (S) for "Larger Is Better option"Figure 4 shows "Main effects plot for Mean S/N ratios" for (D), (U) and (S). The S/N plots obtained from Taguchi analysis shows that the optimum (D), (U) and (S) are visible at Core Material PK2, Core Height $12.7 \mathrm{~mm}$. Face sheet Thickness $.8 \mathrm{~mm}$, and Panel width 50mm.

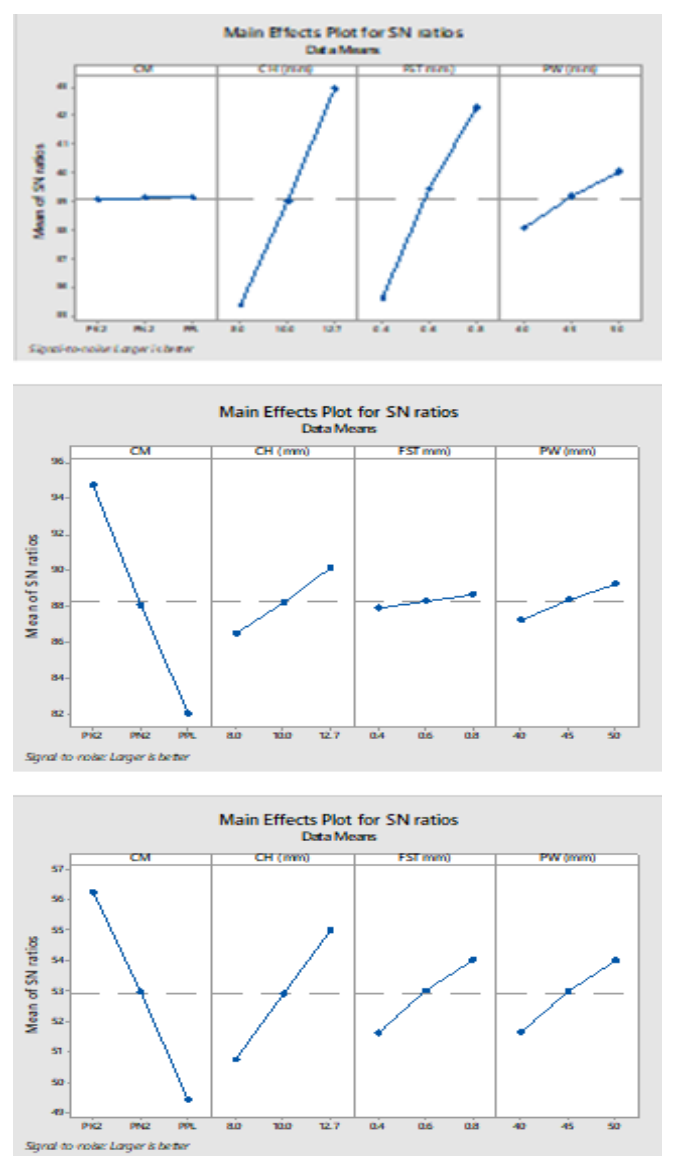

Figure 4- Main effects plot for SN ratios (D, U and S)
For static designs, Minitab offers following $\mathrm{S} / \mathrm{N}$ ratios formula for the "Larger is better" option-

$$
\mathrm{S} / \mathrm{N}=-\mathbf{1 0} * \log \left(\Sigma\left(1 / \mathrm{Y}^{2}\right) / \mathbf{n}\right)
$$

where $\mathrm{Y}=$ responses for the given factor level combination and $n=$ number of responses in the factor level combination.

From the Taguchi analysis of all three responses, as shown above in figure 4, it has been observed that the optimum design has been achieved for Core Material PK2, Core Height 12.7mm. Face sheet Thickness .8 mm, and Panel width $50 \mathrm{~mm}$.

\subsection{GREY RELATION ANALYSIS}

GRA is a tool used for analysis of multi-objective function. The GRA has been performed here to validate or verify the results of the Taguchi Analysis.

GRA utilizes normalization of values to find GRC (grey relational coefficients) and GRG (grey relational

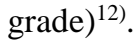

The aim of this research is to find the optimal process level for (D), (U) and (S) of composite sandwich structure. All these characteristics are of the "Larger-is-the better" type. For Larger the better, the most appropriate GRA formulae have been adopted for different optimum value requirement.

The Normalized values and Deviation Sequences have been found for all three response characteristics as shown in table.4. These two steps are necessary for calculating the GREY relation coefficients as the PCA can be performed only on the values of GREY relation Coefficients.

Table 4 - Normalized value and Deviation sequences of Response Characteristics

\begin{tabular}{|c|c|c|c|c|c|c|}
\hline \multirow{2}{*}{$\begin{array}{l}\text { C. } \\
\text { N. }\end{array}$} & \multicolumn{3}{|c|}{ RESPONSES } & \multicolumn{3}{|c|}{$\begin{array}{c}\text { NORMALIZED } \\
\text { VALUES }\end{array}$} \\
\hline & D & $\mathbf{U}$ & S & D & $\mathbf{U}$ & S \\
\hline 1 & 34.65 & 37749.6 & 380.65 & 0 & 0.394 & 0.139 \\
\hline 2 & 93.14 & 54606.96 & 669.10 & 0.309 & 0.642 & 0.497 \\
\hline 3 & 223.8 & 78927.17 & 1074.38 & 1 & 1 & 1 \\
\hline 4 & 68.16 & 23112.5 & 402.70 & 0.177 & 0.179 & 0.167 \\
\hline 5 & 114.68 & 23328 & 440.75 & 0.423 & 0.182 & 0.214 \\
\hline 6 & 94.768 & 30403.34 & 496.37 & 0.317 & 0.286 & 0.283 \\
\hline 7 & 85.738 & 10890 & 267.90 & 0.270 & 0 & 0 \\
\hline 8 & 66.378 & 13520 & 292.08 & 0.167 & 0.038 & 0.029 \\
\hline 9 & 130.293 & 13928.34 & 332.29 & 0.505 & 0.044 & 0.079 \\
\hline \multirow{2}{*}{$\begin{array}{l}\text { C. } \\
\text { N. }\end{array}$} & \multicolumn{6}{|c|}{ DEVIATION SEQUENCES } \\
\hline & & D & & $\mathbf{U}$ & & $\mathbf{S}$ \\
\hline 1 & & 1 & & 5052 & & 3602 \\
\hline 2 & & 0.6908 & & 3574 & & 5025 \\
\hline 3 & & 0 & & 0 & & 0 \\
\hline 4 & & 0.8228 & & 3203 & & 3328 \\
\hline 5 & & 0.5769 & & 3171 & & 7856 \\
\hline 6 & & 0.6822 & & 7131 & & 7167 \\
\hline
\end{tabular}




\begin{tabular}{|c|c|c|c|}
\hline 7 & 0.7299 & 1 & 1 \\
\hline 8 & 0.8323 & 0.9613 & 0.9700 \\
\hline 9 & 0.4944 & 0.9553 & 0.9201 \\
\hline
\end{tabular}

After Calculations of normalized values and deviation sequences, the Grey relation coefficients have been derived for three responses and tabulated in the table 5 as shown below.

Table 5- Values of Grey Relational Coefficients (GRC) for three responses

\begin{tabular}{|r|c|c|c|}
\hline \multirow{2}{*}{\begin{tabular}{c}
\multirow{2}{*}{ S. } \\
N.
\end{tabular}} & \multicolumn{3}{|c|}{ Grey Relation Coefficients } \\
\cline { 2 - 4 } & $\mathbf{D}$ & $\mathbf{U}$ & $\mathbf{S}$ \\
\hline 1 & 0.33333 & 0.452397932 & 0.3675926 \\
\hline 2 & 0.41987 & 0.583121146 & 0.4987398 \\
\hline 3 & 1 & 1 & 1 \\
\hline 4 & 0.37796 & 0.378685878 & 0.3751359 \\
\hline 5 & 0.46425 & 0.379596487 & 0.3889012 \\
\hline 6 & 0.42292 & 0.412134628 & 0.4109432 \\
\hline 7 & 0.40650 & 0.333333333 & 0.3333333 \\
\hline 8 & 0.37528 & 0.342150633 & 0.3401313 \\
\hline 9 & 0.502770 & 0.343561656 & 0.3520741 \\
\hline
\end{tabular}

\subsection{PRINCIPAL COMPONENT ANALYSIS}

(PCA) can be adopted in GRA to find out the weightage for each performance characteristics ${ }^{10)}$. PCA can be utilized to find proper weight for different response characteristics to have an effective GRA ${ }^{11)}$. The PCA can be used to determine the corresponding weighting values of different performance characteristics when GRA is applied to a problem having with multiple-performance characteristics. This always proves to be capable of objectively reflecting the relative importance of different performance characteristic ${ }^{26)}$. Using the Hybrid Taguchi GRA assisted with PCA, the most dominating turning parameters for magnesium alloy on the multiple performances has been found as the depth of $\mathrm{cut}^{27}$ ).So, here also by utilization of PCA, the weighted values for every performance characteristic have been identified. The multiple performance characteristics as shown in the table above showing GRCs of each performance characteristics has been entered in Minitab 18 and the corresponding Eigen values and Eigen-vector related to these Eigen value has also been generated. And ultimately the weighting contribution of each performance characteristic has been identified. The contribution of individual performance characteristics, such as, (D), (U) and Stiffness are shown in table below. The first principal component (PC1) variance contribution is as high as $96 \%$, as mentioned in Table 6.

Table 6- Eigen Value Analysis of the Correlation Matrix

\begin{tabular}{|c|c|c|c|}
\hline Principal Component & PC1 & PC2 & PC3 \\
\hline Eigen value & 2.8795 & 0.1170 & 0.0034 \\
\hline Proportion & 0.960 & 0.039 & 0.001 \\
\hline
\end{tabular}

Table 7- Eigen vectors For Principal Component

\begin{tabular}{|c|c|c|c|}
\hline Variable & PC1 & PC2 & PC3 \\
\hline $\mathbf{D}$ & 0.568 & -0.775 & -0.278 \\
\hline $\mathbf{U}$ & 0.576 & 0.615 & -0.538 \\
\hline $\mathbf{S}$ & 0.588 & 0.146 & 0.796 \\
\hline
\end{tabular}

Table 8- Contribution Calculation for the PC

\begin{tabular}{|c|c|}
\hline $\begin{array}{c}\text { Performance } \\
\text { Characteristic }\end{array}$ & $\begin{array}{c}\text { Contribution/ Weighted } \\
\text { Value }\end{array}$ \\
\hline D & $(0.568)^{2}=.323$ \\
\hline U & $(0.576)^{2}=.332$ \\
\hline S & $(0.588)^{2}=.345$ \\
\hline
\end{tabular}

All the GR Grades has been generated by adopting PCA and the weighted value of all performance characteristic have been calculated as shown in table 9 .

Table 9- Grey relation grades (GRG's)

\begin{tabular}{|c|c|}
\hline Confi. No. & Grey Relation Grades (GRG) \\
\hline 1 & 0.128238835 \\
\hline 2 & 0.164383929 \\
\hline 3 & 0.333333333 \\
\hline 4 & 0.125712423 \\
\hline 5 & 0.137927049 \\
\hline 6 & 0.13854314 \\
\hline 7 & 0.119989853 \\
\hline 8 & 0.117827263 \\
\hline 9 & 0.134865042 \\
\hline
\end{tabular}

\subsection{Determination of Optimal Combination of Input Process Factors and Their Levels}

GRG for each level of process factors has been evaluated to find out the optimum level of different process factors. The maximum value from the GRG has been chosen for each factor. In Table 10, the BOLD ITALIC values of GRG depict the largest value for the different levels of each process factor and Core Material PK2, Core Height 12.7mm. Face sheet Thickness .8 mm, and Panel width $50 \mathrm{~mm}$ for optimum response characteristics.

Table 10- GRG Values C/P to Different Levels of Input Process Factors

\begin{tabular}{|c|c|c|c|c|}
\hline Level & CM & CT & FST & PW \\
\hline $\mathbf{1}$ & $\mathbf{0 . 2 0 8 6 5}$ & 0.124647 & 0.1282 & 0.133676 \\
\hline $\mathbf{2}$ & 0.13406 & 0.140046 & 0.1416 & 0.140972 \\
\hline $\mathbf{3}$ & 0.12422 & $\mathbf{0 . 2 0 2 2 4 7}$ & $\mathbf{0 . 1 9 7 0}$ & $\mathbf{0 . 1 9 2 2 9 1}$ \\
\hline
\end{tabular}

The GRA confirms that the optimum design has is available for Core Material PK2, Core Height $12.7 \mathrm{~mm}$. Face sheet Thickness .8 mm, and Panel width 50mm.

\subsection{CONFIRMATORY TEST}

The Table 11, shown below explains nicely that the results of Taguchi analysis and GRA for the response 
characteristics are in total agreement. Also it has been observed that the optimum values for Deformation for sandwich structure exists at Core Material PK2, Core Height 12.7mm. Face sheet Thickness .8 mm, and Panel width $50 \mathrm{~mm}$.

Table 11- Comparison of results of GRA and Taguchi

\begin{tabular}{|c|c|c|c|}
\hline $\begin{array}{c}\text { INPUT } \\
\text { FACTORS }\end{array}$ & $\begin{array}{c}\text { TAGUCHI } \\
\text { OPTIMAL } \\
\text { VALUES }\end{array}$ & $\begin{array}{c}\text { GRA } \\
\text { OPTIMAL } \\
\text { VALUES }\end{array}$ & LEVEL \\
\hline $\begin{array}{c}\text { Core } \\
\text { Material }\end{array}$ & 1 & 1 & $1(\mathrm{PK} 2)$ \\
\hline $\begin{array}{c}\text { Core } \\
\text { Thickness }\end{array}$ & 3 & 3 & $3(.8 \mathrm{~mm})$ \\
\hline $\begin{array}{c}\text { FS } \\
\text { Thickness }\end{array}$ & 3 & 3 & $3(12.7 \mathrm{~mm})$ \\
\hline $\begin{array}{c}\text { Panel } \\
\text { Width }\end{array}$ & 3 & 3 & $3(50 \mathrm{~mm})$ \\
\hline
\end{tabular}

Table 12- Values of D, U and S for optimized configuration

\begin{tabular}{|c|c|c|}
\hline $\mathbf{D}\left(\mathbf{M N m m}^{\mathbf{2}}\right)$ & $\mathbf{U} \mathbf{( N )}$ & $\mathbf{S} \mathbf{( N / \mathbf { m m } )}$ \\
\hline 223.85 & 78927.1 & 1074.38 \\
\hline
\end{tabular}

The table 12 shows that the 3rd configuration from Taguchi Design has the highest values for the D, U and S as compared to all other Sandwich Panel configurations available in the Taguchi L9 OA. Ultimately it confirms that the Taguchi and GRA analysis are performed in a correct manner. So, the analysis shows that-

1. The stiffness is more for the Kevlar Honeycomb Core i.e. the Kevlar core can provide more stiffness then the other core materials.

2. The graphs of the Taguchi Analysis clearly show that the core height has the highest impact on the different stiffness properties as compared to other design factors. The analysis clearly supports the conclusion that with increase of the core height the stiffness can be enhanced in a significant manner.

3. Facesheet thickness also is an important factor after core height for achieving the higher stiffness values.

4. Panel width is least significant among the different design parameters chosen and it has same effect on all response parameters chosen here.

\section{Conclusion}

The different properties of sandwich structure such as Stiffness and Flexural Strength depends on various design factors such as material of core and facesheet, thickness of facesheet and core, type of core and panel shape etc. In this study, four different factors i.e. Material of Honeycomb core, Core Height, Facesheet Thickness and Panel Width with each having three different values has been chosen and a L9 Orthogonal has been adopted using Taguchi Design in Minitab 18. After that, 9 different samples have been fabricated as per configurations of L9
OA and "Three point bend" test has been performed on these samples. From three point bend test, the values of Bending Stiffness, Rigidity and Equivalent Stiffness has been calculated .After that, Taguchi Analysis has been performed on the output responses.

To calculate the weightage of effect of each process variable on stiffness properties, PCA has been adopted in calculation of GR Grades. The impact of all process variables has been reported systematically using this hybrid technique. It has been observed that the optimum stiffness for the sandwich panel exists at Core Material PK2, Core Height 12.7mm. Face sheet Thickness .8 mm, and Panel width $50 \mathrm{~mm}$ and the values of Bending Stiffness D, Bending Rigidity U and equivalent Stiffness are $223.85 \mathrm{MNmm}^{2}$, $78927.17 \mathrm{~N}$ and $1074.384 \mathrm{~N} / \mathrm{mm}$ for this configuration. Also the composite fabricated using Kevlar® Honeycomb core and carbon fiber facesheet reported excellent stiffness performance for the optimized stiffness variables combination.

\section{Acknowledgements}

I am highly thankful to my co authors i.e. Prof. Surjit Angra and Prof. A.K. Chanda who helped in achieving the results of this research.

\section{References}

1) A. Kumar, S. Angra and A.K. Chanda. "Analysis of the effects of varying core thicknesses of Kevlar Honeycomb sandwich structures under different regimes of testing”, Materials Today: Proceedings, 2020,https://doi.org/10.1016/j.matpr.2019.11.242.

2) L. Wahl, S. Maas and D. Waldma. "Shear stresses in honeycomb sandwich plates: Analytical solution, finite element method and experimental verification”. Journal of Sandwich Structures and Materials. 14. 449 -468. Doi: 10.1177/1099636212444655. (2012).

3) J. Lister. "Study the effects of core orientation and different face thicknesses on mechanical behavior of honeycomb sandwich structures under three point bending”. (2014).

4) L. Liu, H. Wang and Z W. Guan. "Numerical models with layered elements for Nomex honeycomb core under flat wise compression”, 20th International Conference on Composite Materials, Copenhagen, 19-24th July 2015.

5) A. Kumar, A. K. Chanda, S. Angra S "Analysis of effects of varying face sheet thickness on different properties of composite sandwich Structure", Materials Today: Proceedings, 2020, ISSN: 2214-7853.

https://doi.org/10.1016/j.matpr.2020.06.114. .(2020).

6) N. Kaushik and S. Singhal. "Optimization of Wear Properties in Aluminum Metal Matrix Composites using Hybrid Taguchi-GRA-PCA”, International Journal of Performability Engineering, 14(5), 857-870.DOI: $\quad$ 10.23940/ijpe.18.05.p4.857870. (2018). 
7) N. Li, Y. Chen and D. Kong. "Multi-response optimization of Ti-6Al-4V turning operations using Taguchi-based grey relational analysis coupled with kernel principal component analysis". Adv. Manuf. 7, 142-154(2019).https://doi.org/10.1007/s40 436-019-00251-8. (2019).

8) L. Sutherland, F. Alizadeh and G. Soares. Flexural testing of sandwich laminates for steel-composite joints. 10.13140/RG.2.1.4051.2726. (2015).

9) J. Mahaboob, S. S. Ramya, R. Rao, G. Singh. "Multi-Response Optimization of Aluminum alloy using GRA \& PCA by employing Taguchi Method”, International Research Journal of Engineering and Technology, 3 (1), 680-686. (2016).

10) P. Umamaheswarrao, D. RangaRaju, KNS Suman and B. RaviSankar. "Multi objective optimization of process parameters for hard turning of AISI 52100 steel using Hybrid GRA-PCA”. Procedia Computer Science. 133. 703-710. 10.1016/j.procs.2018.07.129. (2018).

11) N. Mehat, S. Kamaruddin, A.R. Othman. "Hybrid Integration of Taguchi Parametric Design, Grey Relational Analysis, and Principal Component Analysis Optimization for Plastic Gear Production”. Chinese Journal of Engineering. 1-11. 10.1155/2014/351206. (2014).

12) N. Kaushik and S. Singhal. "Wear Conduct of Aluminum Matrix Composites: A Parametric Strategy Using Taguchi Based GRA Integrated With Weight Method”.CogentEngineering.5.DOI:10.1080/233119 16.2018.1467196. (2018).

13) S. Jozić, I. Dumanić, D. Bajić. "Experimental analysis and optimization of the controllable parameters in turning of en aw-2011 alloy; dry machining and alternative cooling techniques". FACTA UNIVERSITATIS Series: Mechanical Engineering, 18(1), 13-29.doi.org/10.22190/FUME191024009J. (2020).

14) L. Gibson, M. Ashby. Cellular Solids: Structure and Properties (Cambridge Solid State Science Series). Cambridge: Cambridge University Press. doi:10.1017/CBO9781139878326. (1997).

15) https://www.plascore.com/download/datasheets /honeycomb_data_sheets/PLA_PK2_2019.pdf. (accessed 2019 Jan. 20)

16) J. Arbaoui, Y. Schmitt and F. Royer. "Effect of core thickness and intermediate layers on mechanical properties of polypropylene honeycomb multi-layer sandwich structures”. Archives of metallurgy and material. 59(1):11-16. doi: 10.2478/amm-2014-0002. (2014)

17) S.S. Chauhan and S.C. Bhaduri. "Structural analysis of a Four-bar linkage mechanism of Prosthetic knee joint using Finite Element Method”, EVERGREEN Joint Journal of Novel Carbon Resource Sciences \& Green Asia Strategy, 7(2), 209-215. (2020).

18) S.P. Dwivedi, N. G. Maurya and M. Murya.
"Assessment of Hardness on AA2014/Eggshell Composite Produced via Electromagnetic Stir casting Method”, EVERGREEN Joint Journal of Novel Carbon Resource Sciences \& Green Asia Strategy, 6(4), 285-294. (2019).

19) H. Herranen, O. Pabut, M. Eerme and J. Majak. "Design and Testing of Sandwich Structures with Different Core Materials. Materials Science”, Materials Science (Medžiagotyra), 18(1), 45-50. (2012).

20) N. Weake ,M. Pant, A. Sheoran , A. Haleem and H. Kumar. Optimising Parameters of Fused Filament Fabrication Process to Achieve Optimum Tensile Strength Using Artificial Neural Network", EVERGREEN Joint Journal of Novel Carbon Resource Sciences \& Green Asia Strategy, 7(3), 373-381, September, 2020.

21) A. Mahyudin, S. Arief, H. Abral , Emriadi , M. Muldarisnur and Mila Puteri Artika. "Mechanical Properties and Biodegradability of Areca Nut Fiber-reinforced Polymer Blend Composites", EVERGREEN Joint Journal of Novel Carbon Resource Sciences \& Green Asia Strategy, 7(3), 366-372, September, 2020.

22) A. Catapano and M. Montemurro. "Optimal design of sandwich plates with honeycomb core”, Joint Conference on Mechanical, Design Engineering \& Advanced Manufacturing”, June 2014, France, 1-7.

23) ASTM C393 / C393M-20, Standard Test Method for Core Shear Properties of Sandwich Constructions by Beam Flexure, ASTM International, West Conshohocken, PA, 2020, www.astm.org.

24) M. Prakash, V. Guptha, R. Sharma and B. Mohan. "Influence of Cell Size on the Core Shear Properties of FRP Honeycomb Sandwich Panels”, Materials and Manufacturing Processes, (Taylor \& Francis Group), 27, 169-176. (2012).

25) D. G. Vamja and G. G. Tejani. "Experimental Test on Sandwich Panel Composite Material”, International Journal of Innovative Research in Science, Engineering and Technology, 2(7), July 2013.

26) Zahid A. Khan, S. Kamaruddin, Arshad Noor Siddiquee. "Feasibility study of use of recycled High Density Polyethylene and multi response optimization of injection moulding parameters using combined grey relational and principal component analyses”, Materials \& Design, 31(6), 2925-2931.doi: 10.1016/j.matdes.2009.12.028.

27) R. Viswanathan, S. Ramesh, S. Maniraj, V. Subburam. "Measurement and multi-response optimization of turning parameters for magnesium alloy using hybrid combination of Taguchi-GRA-PCA technique”, Measurement,159,107800,(2020),doi:10.1016/j.meas urement.2020.107800. 


\section{Nomenclature}

PCA Principal Component Analysis

GRA Grey Relation Analysis

$O A \quad$ Orthogonal Array

PK2 Kevlar

PN2 Nomex

PPL Polypropylene 